\title{
DETERMINATION OF SAFETY INDICATORS IN THE DEVELOPED MUFFINS WITH NON-TRADITIONAL RAW MATERIALS
}

\author{
Khrystyna Kovalchuk \\ Department of Commodity Research and Commodity Expertise \\ Lviv Institute of Economics and Touris \\ 8 Mentsynskyi str., Lviv, Ukraine, 79007 \\ khristinakovalchuk@i.ua \\ Halyna Ozimok \\ Department of Commodity Research and Commodity Expertise \\ Lviv Institute of Economics and Touris \\ 8 Mentsynskyi str., Lviv, Ukraine, 79007 \\ ozumok123@gmail.com \\ Ruslan Mariychuk \\ Department of Ecology \\ University of Presov in Presov \\ 1 17th November str., Presov, Slovakia, 08001 \\ ruslan.mariychuk@unipo.sk

\section{Olga Gyrka} \\ Department of commodity science, technology and quality management of food products \\ Lviv Trade and Economic University \\ 10 Tugan-Baranovsky str., Lviv, Ukraine, 79000 \\ lyolya110382@gmail.com
}

\section{Mykhailo Bodak}

Department of commodity science, technology and quality management of food products

Lviv Trade and Economic University

10 Tugan-Baranovsky str., Lviv, Ukraine, 79000

$$
\text { misha_bodak@i.ua }
$$

\section{Nataliya Palko}

Department of food technologies

Lviv Trade and Economic University

10 Tugan-Baranovsky str., Lviv, Ukraine, 79000

palkona@ukr.net

\section{Oksana Davydovych}

Department of food technologies

Lviv Trade and Economic University

10 Tugan-Baranovsky str., Lviv, Ukraine, 79000

oksana_davydovych@ukr.net

\section{Alina Tkachenko}

Department of Commodity Research, Biotechnology, Examination and Customs

Poltava University of Economics and Trade

3 Kovalia str., Poltava, Ukraine, 36014

alina_biaf@ukr.net 


\author{
Liudmyla Huba \\ Department of Commodity research, biotechnology, examination and customs \\ Poltava University of Economics and Trade \\ 3 Kovalia str., Poltava, Ukraine, 36000 \\ lyudmika@gmail.com
}

\begin{abstract}
The aim of research is studying the effect of unconventional raw materials (buckwheat, oatmeal, rye, corn, milk whey, skimmed milk powder, propolis, flower pollen, bean powder, sesame oil, pumpkin seed oil, walnut oil, walnut kernels, candied fruit mixes (apple-cherry fruits of bilberries, natural honey with floral pollen, natural honey with propolis) for the quality and safety of new muffins. The article analyzes the results of the study of the quality and safety indicators of muffins of improved composition, manufactured using non-traditional raw materials. For the preparation of new types of muffins, part of the wheat flour was replaced with buckwheat, corn, oat, milk whey, skimmed milk powder and additives of vegetable origin. Margarine has been replaced by vegetable oils. It has been established that flour confectionery products have high organoleptic properties. From the physico-chemical parameters, the mass fraction of total sugar was determined, which ranged from $28.17 \%$ to $33.07 \%$, the mass fraction of fat $-16.2-20.66 \%$, the mass fraction of moisture $-18.0-22.0$, mass fraction of ash $-0.03-1.3 \%$, alkalinity $0.03-1.8^{\circ}$, the content of toxic elements (copper, zinc, lead, cadmium, arsenic, mercury) and microbiological indicators were also determined. Based on the data obtained as a research result, the expediency of using non-traditional raw materials to expand the range of flour confectionery products, in particular muffins is substantiated.
\end{abstract}

Keywords: muffins, unconventional raw materials, safety, vegetable oils, physical and chemical indicators, toxic elements, microbiological indicators.

DOI: $10.21303 / 2504-5695.2019 .00972$

\title{
1. Introduction
}

Food safety is characterized by the absence of toxic, carcinogenic, mutagenic, or other negative effects on the human body when consumed in conventional quantities. It is guaranteed by the establishment of a regulated level of content, the absence or restriction of the levels of the maximum allowable concentration of pollutants of a chemical and biological nature, as well as natural toxic substances hazardous to the health of consumers. The criteria for determining food safety are the number of toxic elements and microbiological indicators [1, 2].

In the United States, organic confectionery products Justin's Organic Peanut, Butter Cups, TruJoy Sweets, Organic Original Fruit Chews, as well as products based on environmentally friendly honey began to be popular [3].

The result of a survey of Polish consumers indicates that they prefer organic products, since they are healthy, more environmentally friendly and are characterized by pronounced taste, compared with conventional foods. According to consumers, organic products are subject to more stringent control, compared with products made according to traditional recipes [4].

The properties of flour from pumpkin seeds, parsley, mullein, cardamom and thistle after cold pressing have been evaluated. Among the samples studied, the richest in antioxidants and components that slow down cell proliferation are thistle seed flour [5]. The chemical composition and antioxidant activity of the inflorescences of Brassica oleracea L. var. costata DC and acephala and B. rara L. var. rapa. The data on the composition and antioxidant properties of inflorescences of various types are given [6].

Scientists have found that Rhododendron honey, due to the content of phenols and other compounds, has antioxidant activity, antiradical and antimicrobial action [7].

In muffins made from organic raw materials "Grechanik" and "Zhytnitsa" wheat flour was replaced completely and partially - a mixture of wheat flour and rye in the ratio of $34 \%$ and $66 \%$ relative. Lead content is two times less control: $0.01 \mathrm{mg} / \mathrm{kg}$, while in the control $-0.02 \mathrm{mg} / \mathrm{kg}$. Also in the developed products, the arsenic content is significantly lower $-0.03 \mathrm{mg} / \mathrm{kg}$ as compared with $0.15 \mathrm{mg} / \mathrm{kg}$ in the control [8]. As a result of studies of organic wheat, it was revealed that it contains 
a greater amount of useful nutrients as compared to raw materials grown in the traditional way with the use of pesticides. Scientists have found that wheat varieties grown under organic conditions have significantly higher digestibility of protein and starch than wheat grown under inorganic conditions [9]. It was established that between organic and ordinary pea flour there were no significant differences in amino acid composition. However, organic buckwheat flour is characterized by a high biological value than ordinary buckwheat flour [10]. The scientific literature lacks data on the study of consumer properties of finished organic products. Organic raw materials were studied in comparison with raw materials grown in the traditional way, which leads to the scientific novelty of the selected study.

From a safety point of view, the absence of microbiological contamination of products is extremely important. That is why the definition of microbiological indicators in food products, in particular flour confectionery products, is now increasingly important. After all, the consumption of poor-quality products leads to food poisoning. On the value of microbiological indicators affecting the efficiency of heat treatment in the manufacture, the quality of raw materials and semi-finished products (at the stages of preparation, transportation, processing and storage), the quality of washing and disinfection of equipment, devices, microbiological purity of packaging materials, methods of microbiological control, etc.

A variety of raw materials containing carbohydrates, proteins, fats, vitamins, minerals and a high nutritional value not only for humans, but also for many microorganisms are used for flour confectionery products. Raw materials, as a rule, contain from tens of thousands to several millions of microorganisms per $1 \mathrm{~g}$. However, despite this, microbiological processes do not always develop in raw materials. This is due to the fact that for the vital activity of microorganisms, in addition to nutrients, appropriate humidity, temperature and acidity are also needed.

To prevent microbiological deterioration, it is necessary to comply with the relevant sanitary standards for production technology and monitor the sanitary condition in industrial premises.

The aim of research is studying the effect of non-traditional plant materials on the quality and safety of new muffins with improved composition. In the new muffins, part of the flour was replaced with buckwheat, oatmeal, rye flour, corn flour, whey powder and skimmed milk, which increase the amount of essential amino acids in the products. The introduction of powders of medicinal and technical raw materials, beans, blueberries, honey with pollen flower, honey with propolis, a mixture of candied fruit. Walnut kernels affect the improvement of vitamin and mineral composition. Some margarine in new products has been replaced with sesame oil; pumpkin seed oil; walnut oil will increase the proportion of unsaturated fatty acids.

\section{Materials and Methods}

For the study of consumer properties, nutritional and biological value, quality, safety of muffins of improved composition "Sesame", "Seaman", "Toughie", "Autumn Aroma", "Blueberry", "Medoc" and "Elite" were used organoleptic, physicochemical and microbiological analysis methods. The studies were conducted in triplicate and fivefold.

As a result of the study, new muffins were modeled and developed (Table 1).

In the Autumn Aroma muffin, the raisins were completely replaced with candied fruit (apple-cherry) and partially replaced in the Toughie muffing by walnut kernels and Blueberry - blueberry fruits. Muffins with fillings contain the filling of natural honey with "Medoc" pollen and natural honey with propolis - "Elite". For the control sample was taken Stolychnyi muffin, which is made according to the classical recipe [11].

Merchandising quality assessment of the developed muffins new formulations was carried out in accordance with European technical regulations for food products [12].

Mass fraction of total sugar in terms of dry matter (sucrose) in muffins was determined by Permanganate method (by Bertrand), and fat in terms of dry matter - by Soxhlet extraction and weight method (Fig. 1). 
Table 1

The composition of the new muffins

\begin{tabular}{|c|c|c|c|c|c|}
\hline \multirow{2}{*}{$\begin{array}{l}\text { Name of muffin } \\
\text { samples }\end{array}$} & \multicolumn{5}{|c|}{ Nonconventional raw materials and natural supplements } \\
\hline & Flour & Powders and their mixtures & Whey & $\begin{array}{l}\text { Skimmed milk } \\
\text { powder }\end{array}$ & Vegetable oils \\
\hline «Sesame» & rye & $\begin{array}{l}\text { blackberry leaves gray, black currant, } \\
\text { chamomile flowers }\end{array}$ & + & - & sesame \\
\hline «Sailor» & oatmeal & $\begin{array}{l}\text { leaves of bergenia, raspberries, com- } \\
\text { mon butterbur, kelp thallus }\end{array}$ & - & - & pumpkin seeds \\
\hline «Toughie» & buckwheat & peppermint and walnut leaves & + & - & walnut \\
\hline «Autumn Aroma» & corn & $\begin{array}{c}\text { Hypericum herbs perforatum, cardio- } \\
\text { phyllous linden flowers, Echinacea } \\
\text { purpurea }\end{array}$ & - & + & - \\
\hline «Blueberry» & buckwheat & chicory roots, violet tricolor flowers & - & + & - \\
\hline Medoc & corn & cardiophyllous linden flowers, pollen & + & - & pumpkin seeds \\
\hline «Elite» & oatmeal & peppermint leaves, beans, propolis & + & - & - \\
\hline
\end{tabular}

Fig. 1. Soxhlet device

Mass fraction of moisture is carried out in a drying cabinet by drying to constant weight at a temperature of $102^{\circ} \mathrm{C}$ (Fig. 2).

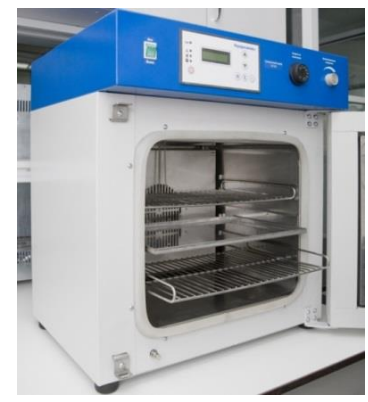

Fig. 2. Drying cabinet for measuring muffin humidity

Alkalinity was determined by a potentiometric method (Fig. 3).

The determination of the mass fraction of ash insoluble in solution with a mass fraction of $10 \%$ hydrochloric acid was determined by wet ashing of the sample in nitric acid and burning it in an electric furnace. The mass fraction of protein substances was determined by the amount of nitrogen according to the Kjeldahl method with subsequent recalculation.

The mineral composition of the muffins was determined by atomic absorption spectrophotometry on a S-115M1-PK atomic absorption spectrophotometer (Semi, Ukraine) (Fig. 4) [13]. 


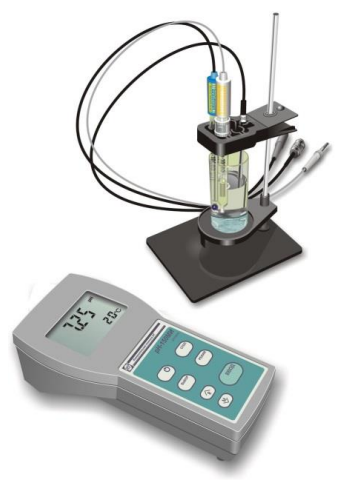

Fig. 3. $\mathrm{pH}$ meter to study the alkalinity of finished products $\mathrm{PH}-150 \mathrm{MI}$

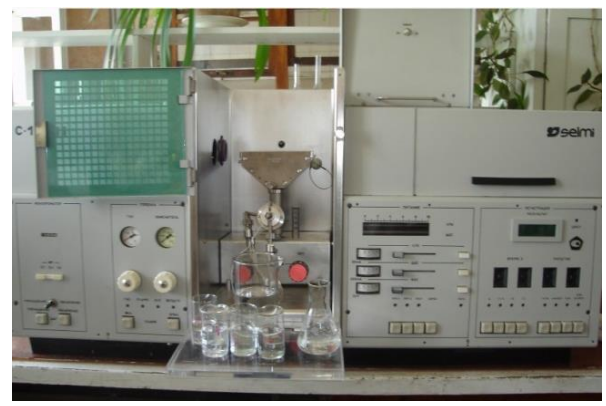

Fig. 4. Atomic absorption spectrophotometer S-115M1-PK

In order to determine the safety of muffins new formulations, standard techniques were used. Thus, copper, zinc, lead and cadmium were determined by the atomic absorption method, arsenic by the colorimetric method, mercury by the method of flameless atomic absorption [13].

Retinol (vitamin A) was determined by a colorimetric method, which is based on the reaction of retinol with antimony trichloride in chloroform (Carr-Price reaction) with the formation of a blue color, the intensity of which is directly proportional to the content of vitamin A. The content of thiamine (vitamin $\mathrm{B}_{1}$ ) was determined by the fluorimetric method. Oxidation of thiamine was in an alkaline medium with the formation of thiochrome. The intensity of the fluorescence of thiochrome is directly proportional to the mass fraction of thiamine. The presence of riboflavin (vitamin $\mathrm{B}_{2}$ ) was determined by direct fluorometry, which is based on the ability of riboflavin to regenerate to a non-fluorescent compound under the influence of sodium hydrosulfite and measure the fluorescence intensity on the fluorometer of the fluorescence extract of a standard riboflavin solution.

Nicotinic acid (vitamin PP) was determined by the method, and its ability, when interacting with rhodane bromide in the presence of aromatic amines (aniline, metol) in a neutral or weakly acidic medium, to form a colored compound (glutaconic aldehyde), which is directly proportional to the amount of nicotinic acid, is determined colorimetrically. The content of ascorbic acid (vitamin C) was determined by the Tillmans method, based on its ability to reduce the sodium of 2,6-dichlorophenolindophenol, which is red in an acidic medium and becomes discolored when it is restored; in alkaline medium the color is blue. Tocopherol (vitamin E) was determined by a colorimetric method, which is based on the reduction of ferric iron tocopherols to bivalent to form a colored complex of bivalent iron with orthophenanthroline, the intensity is directly proportional to the content of vitamin $\mathrm{E}$ [13].

The iodine content was determined by the method of inverse current-current voltammetry on a 3-electrode circuit on an Ecotest-VA analyzer (Fig. 5) [14].

For confectionery products it is necessary to conduct a microbiological assessment of finished products. Among microbial hazards should identify Salmonella spp., Clostridium botulinum, Staphylococcus aurous, Yersinia enterocolitica, Listeria monocytogenes, Vibrio spp., Escherichia coli, Clostridium perfringens, Bacilluscereus, Campylobacter spp., Shigella spp. [15]. 


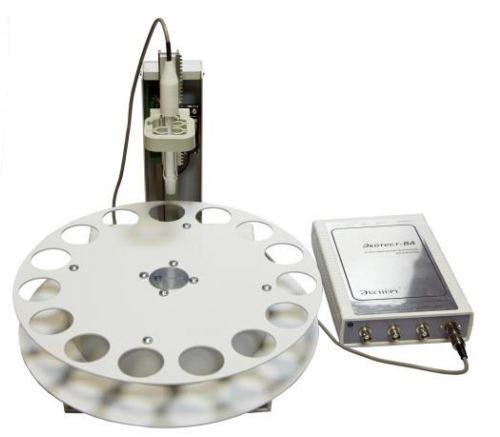

Fig. 5. Ecotest-VA analyzer

\section{Results}

When studying the muffins quality of, the following indicators were determined by physicochemical parameters: mass fraction of total sugar, mass fraction of fat, mass fraction of moisture, alkalinity, mass fraction of ash. The research results are presented in Table 2.

Table 2

Physico-chemical quality indicators of muffins, $p \leq 0.05 ; n=3$

\begin{tabular}{cccccc}
\hline & \multicolumn{3}{c}{ Quality indicator } \\
\cline { 2 - 5 } $\begin{array}{c}\text { Name of muffin } \\
\text { samples }\end{array}$ & $\begin{array}{c}\text { Mass fraction of } \\
\text { total sugar in terms } \\
\text { of dry substance, } \%\end{array}$ & $\begin{array}{c}\text { Mass fraction of } \\
\text { fat in terms of dry } \\
\text { matter, \% }\end{array}$ & $\begin{array}{c}\text { Moisture con- } \\
\text { tent, \% }\end{array}$ & $\begin{array}{c}\text { Alkalinity in } \\
\text { terms of solids, } \\
\text { in degres, not } \\
\text { more than }\end{array}$ & $\begin{array}{c}\text { Mass fraction of ash } \\
\text { insoluble in solution with } \\
\text { a maction of hydro- } \\
\text { chloric acid 10 \%, in \%, } \\
\text { not more than }\end{array}$ \\
\hline Control & $33.07 \pm 1.65$ & $20.27 \pm 1.01$ & $18.0 \pm 0.90$ & $1.8 \pm 0.09$ & $0.07 \pm 0.01$ \\
"Sesame" & $31.47 \pm 1.57$ & $19.61 \pm 0.98$ & $20.0 \pm 1.01$ & $1.6 \pm 0.08$ & $0.06 \pm 0.01$ \\
"Sailor" & $31.14 \pm 1.56$ & $17.14 \pm 0.86$ & $22.0 \pm 1.10$ & $1.4 \pm 0.07$ & $0.05 \pm 0.01$ \\
"Toughie" & $29.76 \pm 1.49$ & $20.66 \pm 1.03$ & $21.9 \pm 1.09$ & $1.3 \pm 0.07$ & $0.04 \pm 0.01$ \\
"Autumn Aroma" & $30.45 \pm 1.52$ & $19.31 \pm 0.97$ & $21.0 \pm 1.05$ & $1.5 \pm 0.08$ & $0.04 \pm 0.01$ \\
"Blueberry" & $30.07 \pm 1.50$ & $19.65 \pm 0.98$ & $20.0 \pm 1.01$ & $1.7 \pm 0.09$ & $0.06 \pm 0.01$ \\
"Medoc" & $27.21 \pm 1.36$ & $16.2 \pm 0.81$ & $21.8 \pm 1.09$ & $1.2 \pm 0.06$ & $1.3 \pm 0.07$ \\
"Elite" & $28.17 \pm 1.41$ & $18.7 \pm 0.94$ & $21.7 \pm 1.09$ & $0.03 \pm 0.01$ & $0.03 \pm 0.01$
\end{tabular}

Note: * in accordance with the approved recipes with the maximum permissible deviation from the calculated

The results of the evaluation of physico-chemical parameters indicate that the samples of muffins comply with the requirements of European regulations, indicated in the source [16].

Since the developed muffins contain organic raw materials, an important step was the study of the safety performance of finished products on the content of toxic elements and microbiological indicators. The research results of the content of toxic elements in the developed muffin using non-traditional raw materials are given in Table 3.

As evidenced by the research results, the content of all toxic elements is significantly lower and does not exceed the maximum permissible levels.

The results of the determination of microbiological indicators of freshly made samples of muffins that were selected in the prescribed manner at the enterprise are presented in Table 4. In particular, the number of mesophilic aerobic and facultative anaerobic microorganisms, bacteria of the group of Escherichia coli, coagulase-positive staphylococcus, pathogenic microorganisms (bacteria of the genus Salmonella), mold fungi and yeast were determined. 
Table 3

The content of toxic elements in muffins, $\mathrm{mg} / \mathrm{kg}, p \leq 0.05$

\begin{tabular}{cccccccc}
\hline \multirow{2}{*}{$\begin{array}{c}\text { Name of muffin } \\
\text { samples }\end{array}$} & \multicolumn{7}{c}{ Toxic elements } \\
\cline { 2 - 8 } & Lead & Cadmium & Arsenic & Mercury & Copper & Zinc & Aflatoxin B \\
\hline Control & $0.017 \pm 0.002$ & $<0.02$ & $0.15 \pm 0.02$ & $<0.01$ & $1.3 \pm 0.19$ & $3.8 \pm 0.53$ & $<0.003$ \\
"Sesame" & $0.012 \pm 0.002$ & $<0.02$ & $0.035 \pm 0.004$ & $<0.01$ & $2.4 \pm 0.21$ & $4.6 \pm 0.50$ & $<0.003$ \\
"Sailor" & $0.023 \pm 0.003$ & $<0.02$ & $0.055 \pm 0.006$ & $<0.01$ & $3.4 \pm 0.22$ & $4.9 \pm 0.40$ & $<0.003$ \\
"Toughie" & $0.010 \pm 0.002$ & $<0.02$ & $<0.02$ & $<0.01$ & $4.2 \pm 0.19$ & $4.0 \pm 0.52$ & $<0.003$ \\
"Autumn Aroma" & $0.012 \pm 0.002$ & $<0.02$ & $0.020 \pm 0.003$ & $<0.01$ & $1.5 \pm 0.20$ & $4.0 \pm 0.51$ & $<0.003$ \\
"Blueberry" & $0.013 \pm 0.002$ & $<0.02$ & $<0.02$ & $<0.01$ & $2.4 \pm 0.30$ & $5.0 \pm 0.40$ & $<0.003$ \\
"Medoc" & $0.04 \pm 0.01$ & $<0.02$ & $0.036 \pm 0.004$ & $<0.01$ & $3.9 \pm 0.15$ & $4.1 \pm 0.41$ & $<0.003$ \\
"Elite" & $0.021 \pm 0.003$ & $<0.02$ & $0.030 \pm 0.004$ & $<0.01$ & $3.9 \pm 0.16$ & $4.6 \pm 0.45$ & $<0.003$
\end{tabular}

Table 4

Microbiological indicators of muffins of improved composition

\begin{tabular}{|c|c|c|c|c|c|c|}
\hline \multirow{3}{*}{$\begin{array}{c}\text { Name of muffin } \\
\text { samples }\end{array}$} & \multicolumn{6}{|c|}{ Microbiological indicator } \\
\hline & \multirow{2}{*}{$\begin{array}{c}\text { Mesophilic, aerobic } \\
\text { and facultative } \\
\text { anaerobic microor- } \\
\text { ganisms, CFU in } 1 \mathrm{~g}\end{array}$} & \multicolumn{3}{|c|}{ The mass of the product in $\mathrm{g}$, in which are not allowed: } & \multirow{2}{*}{$\begin{array}{l}\text { Mold } \\
\text { fungi } \\
\text { CFU in } \\
1 \mathrm{~g}\end{array}$} & \multirow[b]{2}{*}{$\begin{array}{c}\text { Yeast } \\
\text { CFU in } \\
1 \mathrm{~g}\end{array}$} \\
\hline & & $\begin{array}{l}\text { coliform } \\
\text { bacteria }\end{array}$ & $\begin{array}{l}\text { coagulase- } \\
\text { positive sta- } \\
\text { phylococcus }\end{array}$ & $\begin{array}{l}\text { pathogenic microorgan- } \\
\text { isms, in particular bacteria } \\
\text { of the Salmonella genus }\end{array}$ & & \\
\hline Control & $1,7 \cdot 10^{2}$ & not found & not found & not found & not found & not found \\
\hline "Sesame" & $1,4 \cdot 10^{2}$ & not found & not found & not found & not found & not found \\
\hline "Sailor" & $1,1 \cdot 10^{2}$ & not found & not found & not found & not found & not found \\
\hline "Toughie" & $1,3 \cdot 10^{2}$ & not found & not found & not found & not found & not found \\
\hline "Autumn Aroma" & $1,2 \cdot 10^{2}$ & not found & not found & not found & not found & not found \\
\hline "Blueberry" & $1,5 \cdot 10^{2}$ & not found & not found & not found & not found & not found \\
\hline "Medoc" & $0,9 \cdot 10^{2}$ & not found & not found & not found & not found & not found \\
\hline "Elite" & $1,1 \cdot 10^{2}$ & not found & not found & not found & not found & not found \\
\hline
\end{tabular}

Microbiological studies of developed muffins using non-traditional raw materials indicate that the number of mesophilic aerobic and optional anaerobic microorganisms does not exceed the established standards for this product. In the test samples, no coliform bacteria, coagula-positive staphylococcus, Salmonella bacteria, mold fungi and yeast were detected, confirming the safety of the newly developed products.

\section{Conclusions}

1. Formulations of improved muffins based on organic certified raw materials have been developed. For the preparation of new muffins "Sesame", "Seaman", "Toughie", "Autumn aroma", "Blueberry", "Medoc" and "Elite" the following raw materials were used: rye flour, oatmeal, buckwheat, corn flour, blackberry leaf powders with gray, black currants, thick leaves, raspberries, common butterbur, peppermint, walnut, cardiophyllous linden flowers, chamomile, tricolor violet, kelp thallus, Hypericum perforatum, chicory roots, purple echinacea, bean, natural honey, pollen, propolis, chicory roots, purple echinacea, purple bean dry milk whey, skimmed 
milk powder, sesame oil, pumpkin seeds, walnuts, walnut kernels, candied apple-cherry fruits and blueberries.

2. Physico-chemical parameters were determined by the mass fraction of total sugar, which ranged from $28.17 \%$ to $33.07 \%$, the mass fraction of fat $-16.2-20.66 \%$, the mass fraction of moisture $-18.0-22.0 \%$, alkalinity $-0.03-1.8^{\circ}$, mass fraction of ash $-0.03-1.3 \%$. The results show that the sample muffins comply with the requirements of European regulations.

3 . The content of toxic elements was determined: copper $-1.2-4.5$, zinc $-4.0-5.0$, lead $0.010-0.04$, cadmium $-<0.02$, arsenic $-0.020-0.055$, mercury $-<0.01$ and aflatoxin $\mathrm{B}_{1}-<0.003$. The obtained figures do not exceed the maximum permissible levels.

4. The study of microbiological indicators of muffins reformulated with non-traditional raw materials (the number of mesophilic aerobic and facultative anaerobic bacteria, Escherichia coli, coagulase staphylococcus, pathogens (Salmonella spp), molds and yeasts) confirmed the safety of the developed products.

The strengths of research are that in the developed muffins using unconventional raw materials, physico-chemical and safety indicators are defined. According to the results of the analysis it was established that these indicators are within the normal range. The research weaknesses are that the quality and safety indicators of muffins during storage have not been studied. This will be a further step in our research.

\section{References}

[1] Peresichnyi, M. I., Korzun, V. N., Kravchenko, M. F. et. al. (2003). Kharchuvannia liudyny i suchasne dovkillia: teoriya i praktyka. Kyiv: KNTEU, 526.

[2] Polyakova, S. P. (2011). Sanitarno-gigienicheskoe sostoyanie predpriyatiya kak faktor formirovaniya mikroflory muchnyh konditerskih izdeliy. Konditerskoe proizvodstvo, 1, 30-31.

[3] Organic confectionery market continues to grow. Available at: https://www.hartman-group.com/files/news/Organic-confectionery-market-continues-to-grow-Candy-Industry.pdf

[4] Bryła, P. (2016). Organic food consumption in Poland: Motives and barriers. Appetite, 105, 737-746. doi: https://doi.org/ 10.1016/j.appet.2016.07.012

[5] Parry, J. W., Cheng, Z., Moore, J., Yu, L. L. (2008). Fatty Acid Composition, Antioxidant Properties, and Antiproliferative Capacity of Selected Cold-Pressed Seed Flours. Journal of the American Oil Chemists' Society, 85 (5), 457-464. doi: https:// doi.org/10.1007/s11746-008-1207-0

[6] Sousa, C., Taveira, M., Valentão, P., Fernandes, F., Pereira, J. A., Estevinho, L. et. al. (2008). Inflorescences of Brassicacea species as source of bioactive compounds: A comparative study. Food Chemistry, 110 (4), 953-961. doi: https://doi.org/10.1016/ j.foodchem.2008.02.087

[7] Silici, S., Sagdic, O., Ekici, L. (2010). Total phenolic content, antiradical, antioxidant and antimicrobial activities of Rhododendron honeys. Food Chemistry, 121 (1), 238-243. doi: https://oi.org/10.1016/j.foodchem.2009.11.078

[8] Tkachenko, A., Birta, G., Burgu, Y., Floka, L., Kalashnik, O. (2018). Substantiation of the development of formulations for organic cupcakes with an elevated protein content. Eastern-European Journal of Enterprise Technologies, 3 (11 (93)), 51-58. doi: https://doi.org/10.15587/1729-4061.2018.133705

[9] Nitika, Punia, D., Khetarpaul, N. (2008). Physico-chemical characteristics, nutrient composition and consumer acceptability of wheat varieties grown under organic and inorganic farming conditions. International Journal of Food Sciences and Nutrition, 59 (3), 224-245. doi: https://doi.org/10.1080/09637480701523249

[10] Krumina-Zemture G., Beitane I., Gramatina I. (2016). Amino acid and dietary fiber content of pea and buckwheat flours. Food science, 1, 84-90.

[11] Keksy i rulety (sbornik retseptur). Available at: https://zinref.ru/000_uchebniki/02700kulinaria/003_00_sbornik_retseptur_ muchnykh_konditerskikh_izdeliy/029.htm

[12] Regulation (EC) No. 854 of the European Parliament and of the Council. Laying down specific rules for the organisation of official controls on products of animal origin intended for human consumption (2004). Official Journal of the European Union, 45.

[13] AACC International. Methods 10-50D and 10-52. Approved Methods of the American Association of Cereal Chemists, 10th ed. AACC International, St. Paul, MN, U.S.A., 2000.

[14] Makarchuk, T. A., Podrushniak, A. Ye., Kravtsova, Yu. V., Koval, A. V. et. al. (2003). Vyznachennia vmistu yodu v kharchovykh produktakh metodom inversiynoi voltamperometriyi. Perspektivnye napravleniya razvitiya pischevoy promyshlennosti: sb. nauch. statey nauch.-prakt. konf. Odessa: OTSNTEI, 94-98. 
[15] Oleksienko, N., Obolkina, V., Dudko, S., Baldyniuk, O. (2015). Bezpechnist kondyterskoi produktsiyi: deiaki aspekty yii formuvannia. Prodovolcha industriia APK, 3, 37-40.

[16] Corrigendum to Regulation (EC) No 854/2004 of the European Parliament and of the Council of 29 April 2004 laying down specific rules for the organisation of official controls on products of animal origin intended for human consumption (2004). Official Journal of the European Union L 139, 83-127.

\title{
FEATURES OF DETERMINING THE QUALITY OF ETHNIC SOURDOUGHS AND WAYS OF USING THEM IN BAKING AND CATERING BUSINESS
}

\author{
Tetiana Lebedenko \\ Department of bread, confectionery, macaroni products and food concentrates technology \\ Odessa National Academy of Food Technologies \\ 112 Kanatna str., Odessa, Ukraine, 65039 \\ tatyanalebedenko27@gmail.com \\ Viktoriia Kozhevnikova \\ Department of hotel and catering business \\ Odessa National Academy of Food Technologies \\ 112 Kanatna str., Odessa, Ukraine, 65039 \\ kozhevnikova-viktoriya@ukr.net \\ Tamara Novichkova \\ Department of hotel and catering business \\ Odessa National Academy of Food Technologies \\ 112 Kanatna str., Odessa, Ukraine, 65039 \\ vicnov@ukr.net \\ Olena Kotuzaki \\ Department of bread, confectionery, macaroni products and food concentrates technology \\ Odessa National Academy of Food Technologies \\ 112 Kanatna str., Odessa, Ukraine, 65039 \\ elenalkotuzaki@gmail.com
}

\footnotetext{
Abstract

The usage of various sourdoughs increases in order to expand the range and improve the quality, nutritional properties, and safety of bread products. Spontaneous sourdoughs with different formulas and preparation parameters are used in technologies of popular ethnic products. This paper is devoted to the study of wheat spontaneous sourdoughs, such as hop, pea-anise, and wine yeast sourdough. The effect of the grade and baking properties of flour, the inclusion of additional ingredients that can act as enrichers of the nutrient medium, carriers of additional fermentation microorganisms, as well as controllers of the species composition of the microflora, on their quality has been studied.

The basic scheme of preparing spontaneous wheat sourdough is developed; the basic stages and parameters of the dilution and production cycles are noted. The methods of controlling the process and quality of sourdough are described, the recommended values of the lifting force and titrated acidity are presented, as well as sensory characteristics.
} 